\title{
Synergistic effects of Chrysanthemum indicum ethanol extract with antibiotics against oral pathogens
}

\author{
Kyung-Yeol Lee ${ }^{1 *}$, Su-Mi Cha ${ }^{1}$, Sung-Mi Choi ${ }^{2}$, Eun-Jin Jang ${ }^{3 *}$, Jeong-Hun Seo ${ }^{4}$ and Jeong-Dan Cha ${ }^{4 *}$ \\ ${ }^{1}$ Department of Oral Microbiology and Institute of Oral Bioscience, Chonbuk National University, Jeonju, Republic of Korea \\ ${ }^{2}$ Department of Dental Hygiene, Daegu Health College, Daegu, Republic of Korea \\ ${ }^{3}$ Department of Dental Technology, Daegu Health College, Daegu, Republic of Korea \\ ${ }^{4}$ Research Manager, Material Development Team, R\&D Center, General Bio Co., Ltd., Namwon, Republic of Korea \\ ${ }^{\#}$ Kyung-Yeol Lee and Sung-Mi Choi contributed equally to this work
}

\begin{abstract}
Wild chrysanthemum (Chrysanthemum indicum) is one of well-known medicinal plants traditionally used in Korea. This study aimed to investigate the synergistic antibacterial activity of $C$. indicum ethanol extract (CIE) with existing antimicrobial agents against oral pathogen. The synergistic effects and anti-biofilm of CIE were evaluated against oral bacteria, either alone or with antibiotics, via broth dilution method and crystal violet assays. MIC/MBC values for CIE, ampicillin, and gentamicin all the tested bacteria ranged between 2-32/4-64 microg/mL, 0.0625-16/0.125-32 microg/mL, and 2-256/8-512 microg/mL, respectively. The synergistic effects were exhibited on CIE with antibiotics against oral bacteria at fractional inhibitory concentration index (FICI) $<0.5$. Moreover, CIE and antibiotics were found to synergistically reduce biofilm formation. 1-6 hours of treatment with 1/2 MIC of CIE with 1/2 MIC of antibiotics resulted from an increase of the rate of killing in units of $\mathrm{CFU} / \mathrm{mL}$ to a greater degree than was observed with alone. These results suggest that the CIE is important in the antibacterial actions of oral pathogen agents.
\end{abstract}

\section{Introduction}

Many oral diseases have been known as chronic bacterial infectious diseases, such as caries, periodontitis, and periimplantitis [1,2]. Some microorganisms, such as Streptococcus, Lactobacillus, and Actinomyces species, can colonize and form pathogenic plaque biofilms on the tooth surface, and have proven to be the main cause of oral infectious diseases $[3,4]$. Effectively inhibiting the growth of planktonic pathogenic bacteria and the formation of biofilms on the tooth surface is the basis for the prevention and treatment of oral diseases [5,6]. Virulent biofilms firmly attached to the oral surface are the main cause of infection diseases in the oral cavity, including dental caries and periodontal disease $[7,8]$. Recent reports have suggested a potential role of periodontal infections in more serious systemic diseases, including cardiovascular disease, respiratory infections, and diabetes, which have a significant impact on the overall health of infected individuals [9-11]. Mechanical dental plaque removal is an efficient procedure to prevent periodontitis and caries $[12,13]$. However, the use of chemical compounds as a complementary method is also necessary and has proven to be a valuable tool to decrease tooth biofilm formation [14].

Natural products are a major source of new natural drugs and can help increase the use of alternative medicines for health care over the past decades [15,16]. Chrysanthemum indicum (L.) des monl. (compositae), spreading widely in Korea, is a well-known herb with small yellow flowers [17]. Oriental traditional medicine has used the aerial parts (stems, leaves and flowers) of C. indicum to treat vertigo, several infectious diseases such as pneumonia, colitis, stomatitis, carbuncle, and fever and human diseases, including inflammatory diseases, oxidant stress, respiratory diseases, cancer, and hypertension [17-22]. Its flowers are also commonly used as tea to treat some eye diseases in Asia traditional medicine [23]. Several chemical compounds isolated from C. indicum flowers were also found to exhibit inhibitory activity against nitric oxide (NO) in lipopolysaccharide-activated macrophages and rat lens aldose reductase [24-26]. In recent years, the chemical composition of essential oil of air-dried C. indicum flowers has been studied, antibacterial activity of its oil has also been confirmed against Staphylococcus aureus, Escherichia coli and Streptococcus pneumoniae $[27,28]$.

In this study, the antimicrobial activities of aerial parts (stems, leaves and flowers) of C. indicum ethanol extract (CIE) against oral bacteria were assessed using broth microdilution method and timekill methods and crystal violet assay for synergistic effect and biofilm formation of the combination with antibiotics.

\section{Materials and methods}

\section{Bacterial strains}

The oral bacterial strains used in this study were: Streptococcus mutans ATCC 25175, Streptococcus sanguinis ATCC 10556, Streptococcus sobrinus ATCC 27607, Streptococcus ratti KCTC (Korean collection for type cultures) 3294, Streptococcus criceti KCTC 3292, Streptococcus anginosus ATCC 31412, Streptococcus gordonii ATCC 10558, Aggregatibacter actinomycetemcomitans ATCC 43717,

${ }^{\star}$ Correspondence to: Jeong-Dan Cha, Research Manager, Material Development Team, R\&D Center, General Bio Co., Ltd., 254 Yongtusna-ro, Songdong-myeon, Namwon-si, Jeollabuk-do, 55793 Republic of Korea, Tel. +82-63-263-0001; Fax: +82-70-5101-1563; E-mail: joungdan@jbnu.ac.kr

Key words: Chrysanthemum indicum, antibacterial activity, oral pathogen, biofilm formation, synergistic effect, minimum inhibitory concentrations (MICs), minimum bactericidal concentrations (MBCs)

Received: June 14, 2019; Accepted: July 04, 2019; Published: July 08, 2019 
Fusobacterium nucleatum ATCC 10953, Prevotella intermedia ATCC 25611, and Porphylomonas gingivalis ATCC 33277. Brain-Heart Infusion (Difco Laboratories, Detroit, MI) broth supplemented with $1 \%$ yeast extract (Difco) was used for all bacterial strains except $P$. intermedia and $P$. gingivalis. For $P$. intermedia and P. gingivalis, BHI broth containing hemin $1 \mu \mathrm{g} / \mathrm{mL}$ (Sigma, St. Louis, MO, USA) and menadione $1 \mu \mathrm{g} / \mathrm{mL}$ (Sigma) was used.

\section{Minimum inhibitory concentrations/minimum bactericidal concentrations assay}

The minimum inhibitory concentrations (MICs) were determined for CIE by the broth dilution method and were carried out in triplicate. The antibacterial activities were examined after incubation at $37^{\circ} \mathrm{C}$ for $18 \mathrm{~h}$ (facultative anaerobic bacteria), for $24 \mathrm{~h}$ (microaerophilic bacteria), and for 1-2 days (obligate anaerobic bacteria) under anaerobic conditions. MICs were determined as the lowest concentration of test samples that resulted in a complete inhibition of visible growth in the broth. $\mathrm{MIC}_{50 \mathrm{~S}}$ and $\mathrm{MIC}_{90}$ s were defined as MICs in which 50 and $90 \%$ of oral bacteria were inhibited, respectively. Following anaerobic incubation of MICs plates, the minimum bactericidal concentrations (MBCs) were determined on the basis of the lowest concentration of CIE that kills $99.9 \%$ of the test bacteria by plating out onto each appropriate agar plate. Ampicillin and gentamicin (Sigma) were used as standard antibiotics in order to compare the sensitivity of CIE against oral bacteria.

\section{Checker-board dilution test}

The antibacterial effects of a combination of CIE, which exhibited the highest antimicrobial activity, and antibiotics were assessed by the checkerboard test as previously described $[29,30]$. The antimicrobial combinations assayed included CIE with antibiotics, ampicillin and gentamicin. Serial dilutions of two different antimicrobial agents were mixed in cation-supplemented Mueller-Hinton broth. After 24-48 hr of incubation at $37^{\circ} \mathrm{C}$, the MICs were determined to be the minimal concentration at which there was no visible growth and MBCs were determined on the basis of the lowest concentration of CIE that kills $99.9 \%$ of the test bacteria by plating out onto each appropriate agar plate. The fractional inhibitory concentration (FIC)/ fractional bactericidal concentration (FBC) index was calculated according to the equation: $\mathrm{FIC} / \mathrm{FBC}$ index $=\mathrm{FIC} / \mathrm{FBC}_{\mathrm{A}}+\mathrm{FIC} / \mathrm{FBC}_{\mathrm{B}}=(\mathrm{MIC} / \mathrm{MBC}$ of drug $\mathrm{A}$ in combination/MIC/MBC of drug $\mathrm{A}$ alone $)+(\mathrm{MIC} / \mathrm{MBC}$ of drug $B$ in combination/MIC/MBC of drug B alone). The FIC and FBC index are the sum of the FICs and FBCs of each of the drugs, which in turn is defined as the MIC and MBC of each drug when it is used in combination divided by the MIC and $\mathrm{MBC}$ of the drug when it is used alone. The interaction was defined as synergistic if the FIC and FBC index was less than or equal to 0.5 , additive if the FIC and FBC index was greater than 0.5 and less than or equal 1.0, indifferent if the FIC and FBC index was greater than 1.0 and less than or equal to 2.0 , and antagonistic if the FIC and FBC index was greater than 2.0.

\section{Biofilm formation assay}

Evaluation of the effect of CIE on biofilm formation of oral bacteria by crystal violet biofilm formation assay was performed according to previous studies [14,31]. Briefly, $200 \mu \mathrm{L}$ aliquots of treated oral bacteria (final concentration of $1.0 \times 10^{6} \mathrm{CFU} / \mathrm{mL}$ ) at sub-lethal dose of CIE $(1 / 4$ MIC) plus antibiotics (1/8 MIC) was transferred to a flat-bottomed sterile polystyrene microplate, and incubated for $24-48 \mathrm{~h}$ at $37^{\circ} \mathrm{C}$ under anaerobic conditions to form biofilm. Then, cells were washed with phosphate-buffered saline (PBS), stained with $0.1 \%$ (wt $/ \mathrm{vol}$ ) crystal violet solution for $15 \mathrm{~min}$, washed with PBS, and de-stained with $96 \%$ ethanol $10 \mathrm{~min}$ in order to fix the cells. Thereafter, the wells were rinsed and air-dried. 33\% (vol/vol) acetic acid was then added to each well and biofilm formation was quantified by measuring the absorbance of the solution at $540 \mathrm{~nm}$ using a microplate reader (BMG LABTECH, USA).

\section{Time-kill and growth inhibition curves assay}

Bactericidal activities of the drugs under study were also evaluated using time-kill curves on oral bacteria. Tubes containing MuellerHinton supplemented to which antibiotics had been added at concentrations of the $\mathrm{MIC}_{50}$ were inoculated with a suspension of the test strain, giving a final bacterial count between $5 \sim 7 \times 10^{6} \mathrm{CFU} / \mathrm{mL}$. The tubes were thereafter incubated at $37^{\circ} \mathrm{C}$ in an anaerobic chamber and viable counts were performed at $0,0.5,1,2,3,4,5,6,12$ and $24 \mathrm{~h}$ after addition of antimicrobial agents, on agar plates incubated for up to 48 $\mathrm{h}$ in anaerobic chamber at $37^{\circ} \mathrm{C}$. Antibiotic carryover was minimized by washings by centrifugation and serial 10 -fold dilution in sterile phosphate-buffered saline, $\mathrm{pH}$ 7.3. Colony counts were performed in duplicate, and means were taken. The solid media used for colony counts were BHI agar for streptococci and BHI agar containing hemin and menadione for $P$. intermedia and P. gingivalis.

\section{Statistical analysis}

Experiments were performed three times and statistical analyses were performed with parametric tests (two-way analysis of variance [ANOVA] and Tukey's test) using commercial software (SPSS 22.0). The results were expressed as mean values \pm standard errors (mean \pm $\mathrm{SE})$ and were considered significant at the level of $\mathrm{p}<0.05$.

\section{Results and discussion}

\section{Minimum inhibitory concentrations/minimum bactericidal concentrations of CIE and antibiotics}

The main etiological factor of dental caries and periodontal disease is dental plaque $[3,7,32,33]$. Therefore, it is reasonable to search for natural products that have antiplaque properties and antimicrobial activity against oral pathogens $[15,31,34,35]$. The active molecules in C. indicum are glycosides and flavonoids; the plant has the ability to act as antibiotic against many species of bacterial pathogens [18,27,36,37]. CIE was evaluated for their antimicrobial activities against eleven common bacterial species present in the oral cavity. The results of the antimicrobial activity showed that CIE exhibited antimicrobial activities against cariogenic bacteria at MICs, 4 to $32 \mu \mathrm{g} / \mathrm{mL}$; MBCs, 4 to $64 \mu \mathrm{g} / \mathrm{mL}$, against periodontopathogenic bacteria at MICs, 2 to $32 \mu \mathrm{g} / \mathrm{mL}$; MBCs, 8 to $64 \mu \mathrm{g} / \mathrm{mL}$ and for ampicillin, either $0.0625 / 0.125$ or $16 / 32 \mu \mathrm{g} / \mathrm{mL}$; for gentamicin, either $2 / 8$ or $256 / 512 \mu \mathrm{g} / \mathrm{mL}$ on tested all bacteria (Table 1). The $\mathrm{MIC}_{50}$ and $\mathrm{MIC}_{90}$ ranges of CIE were from 0.5 to $16 \mu \mathrm{g} / \mathrm{mL}$ and 2 to $32 \mu \mathrm{g} / \mathrm{mL}$, respectively. The CIE showed the strongest antimicrobial activity against $S$. gordonii and $P$. gingivalis, at MIC/MBC, $2 / 4-8 \mu \mathrm{g} / \mathrm{mL}$ than other bacteria at MIC/MBC, $8-32 / 32-64 \mu \mathrm{g} / \mathrm{mL}$.

\section{Synergistic effect of CIE with antibiotics}

Many antimicrobial preparations, such as conventional antibiotics, chlorhexidine (CHX), phenolic compounds and triclosan, can inhibit bacteria and biofilm effectively [38-42]. However, extensive use of these antimicrobial agents can lead to some side-effects, such as tooth staining, calculus formation, drug resistance and gastrointestinal reactions [42, 43]. Therefore, searching for new antimicrobial molecules, which exhibit few or no side-effects and long-term retention in oral cavity, has been intensified in recent years [44]. Combinations of some herbal materials and different antibiotics might affect the inhibitory effect of these antibiotics $[34,45]$. The synergistic effects of 
CIE alone or with antibiotics were evaluated in oral bacteria (Tables 2 and 3). In combination with CIE, the MIC for ampicillin was reduced $\geq 4$-fold in tested bacteria, except $S$. ratti and $S$. criceti, producing a synergistic effect as defined by FICI $\leq 0.5$. The MBC for ampicillin was shown synergistic effects in S. sanguinis, A. actinomycetemcomitans, and $P$. gingivalis by $\mathrm{FBCI} \leq 0.5$ (Table 2 ). In combination with $\mathrm{CIE}$, the MIC for gentamicin was reduced $\geq 4$ fold in all tested bacteria expect $A$. actinomycetemcomitans and F. nucleatum by FICI $\leq 0.5$ and MBC in $S$. anginosus, $P$. intermedia, and $P$. gingivalis by $\mathrm{FBCI} \leq 0.5$ (Table 3 ).

\section{Anti-biofilm formation of CIE with antibiotics}

Oral diseases, such as dental caries, periodontal disease are directly linked with the ability of bacteria to form biofilm $[1,13,46]$. Biofilm in the form of supragingival and subgingival plaque is the etiologic agent in dental caries and periodontal diseases $[4,32]$. Flavonoids and proanthocyanidins isolated from fresh cranberry fruit were found to inhibit growth and biofilm formation of same periodontal pathogens $P$. gingivalis, $S$. mutans and other oral streptococci $[35,47,48]$. C. indicum extracts have also been shown to exhibit antibacterial, antiviral, immunomodulatory, hepatoprotective, and bone remodeling activities, which may be due to the presence of flavonoids, terpenoids, and phenolic compounds in the extracts $[17,19,22,23,26]$. In this study, CIE 1/4 MIC with ampicillin 1/8 MIC effectively inhibited the biofilm formation of S. sanguinis, A. actinomycetemcomitans, and P. gingivalis, with $\leq 25 \%$ inhibition, for gentamicin $1 / 8 \mathrm{MIC}$ at the inhibited the biofilm formation of $S$. anginosus, $P$. intermedia, and $P$. gingivalis with $\leq 25 \%$ inhibition (Figure 1). The CIE showed strong antibiofilm formation against cariogenic and periodontic bacteria.

Table 1. Antibacterial activity of CIE and antibiotics in oral bacteria

\begin{tabular}{|c|c|c|c|c|c|}
\hline \multirow{3}{*}{$\begin{array}{c}\text { Samples } \\
\text { S. mutans ATCC } 25175^{1}\end{array}$} & \multicolumn{3}{|c|}{ CIE $(\mu \mathrm{g} / \mathrm{mL})$} & Ampicillin & Gentamicin \\
\hline & $\mathrm{MIC}_{50<}$ & MIC $_{90<}$ & $\mathrm{MIC} / \mathbf{M B C}^{3}$ & \multicolumn{2}{|c|}{$\mathrm{MIC} / \mathrm{MBC}(\mu \mathrm{g} / \mathrm{mL})$} \\
\hline & 4 & 16 & $16 / 32$ & $0.125 / 0.25$ & $16 / 16$ \\
\hline S. sanguinis ATCC 10556 & 2 & 8 & $8 / 32$ & $0.125 / 0.5$ & $16 / 32$ \\
\hline S. sobrinus ATCC 27607 & 16 & 32 & $32 / 32$ & $0.0625 / 0.25$ & $16 / 32$ \\
\hline S. ratti KCTC 3294² & 4 & 16 & $16 / 32$ & $0.25 / 0.5$ & $16 / 32$ \\
\hline S. criceti KCTC 3292 & 8 & 32 & $32 / 64$ & $0.0625 / 0.125$ & $8 / 16$ \\
\hline S. anginosus ATCC 31412 & 4 & 8 & $8 / 32$ & $0.125 / 0.25$ & $8 / 32$ \\
\hline S. gordonii ATCC 10558 & 1 & 4 & $4 / 4$ & $0.125 / 0.5$ & $16 / 32$ \\
\hline A. actinomycetemcomitans ATCC 43717 & 8 & 32 & $32 / 64$ & $8 / 32$ & $16 / 32$ \\
\hline F. nucleatum ATCC 51190 & 2 & 16 & $16 / 32$ & $16 / 32$ & $2 / 8$ \\
\hline P. intermedia ATCC 49049 & 2 & 8 & $8 / 32$ & $2 / 4$ & $32 / 64$ \\
\hline P. gingivalis ATCC 33277 & 0.5 & 2 & $2 / 8$ & $0.25 / 0.5$ & $256 / 512$ \\
\hline
\end{tabular}

${ }^{1}$ American Type Culture Collection (ATCC)

${ }^{2}$ Korean collection for type cultures (KCTC)

${ }^{3}$ Minimum inhibitory concentration/minimum bactericidal concentration (MIC/MBC)

Table 2. Synergistic effects of CIE with ampicillin against oral bacteria

\begin{tabular}{|c|c|c|c|c|c|c|}
\hline \multirow{2}{*}{ Strains } & \multirow{2}{*}{ Agent } & \multicolumn{2}{|c|}{ MIC/MBC $(\mu \mathrm{g} / \mathrm{mL})$} & \multirow{2}{*}{ FIC } & \multirow{2}{*}{ FICI $^{2}$} & \multirow{2}{*}{ Outcome } \\
\hline & & Alone & Combination $^{1}$ & & & \\
\hline \multirow{2}{*}{$\begin{array}{c}\text { S. mutans } \\
\text { ATCC } 25175^{3}\end{array}$} & CIE & $16 / 32$ & $4 / 16$ & $0.25 / 0.5$ & \multirow{2}{*}{$0.5 / 1.0$} & \multirow{2}{*}{ Synergistic/ Additive } \\
\hline & Ampicillin & $0.125 / 0.25$ & $0.0313 / 0.125$ & $0.25 / 0.5$ & & \\
\hline \multirow{2}{*}{$\begin{array}{l}\text { S. sanguinis } \\
\text { ATCC } 10556\end{array}$} & CIE & $8 / 32$ & $2 / 8$ & $0.25 / 0.25$ & \multirow{2}{*}{$0.5 / 0.5$} & \multirow{2}{*}{ Synergistic/ Synergistic } \\
\hline & Ampicillin & $0.125 / 0.5$ & $0.0313 / 0.125$ & $0.25 / 0.25$ & & \\
\hline \multirow{2}{*}{$\begin{array}{l}\text { S. sobrinus } \\
\text { ATCC } 27607\end{array}$} & CIE & $32 / 32$ & $8 / 16$ & $0.25 / 0.5$ & \multirow{2}{*}{$0.5 / 0.75$} & \multirow{2}{*}{ Synergistic/ Additive } \\
\hline & Ampicillin & $0.0625 / 0.25$ & $0.0156 / 0.0625$ & $0.25 / 0.25$ & & \\
\hline \multirow{2}{*}{$\begin{array}{c}\text { S. ratti } \\
\text { KCTC } 3294^{4}\end{array}$} & CIE & $16 / 32$ & $4 / 8$ & $0.25 / 0.25$ & \multirow{2}{*}{$0.75 / 0.75$} & \multirow{2}{*}{ Additive/ Additive } \\
\hline & Ampicillin & $0.25 / 0.5$ & $0.125 / 0.25$ & $0.5 / 0.5$ & & \\
\hline \multirow{2}{*}{$\begin{array}{c}\text { S. criceti } \\
\text { KCTC } 3292\end{array}$} & CIE & $32 / 64$ & $8 / 16$ & $0.25 / 0.25$ & \multirow{2}{*}{$0.75 / 0.75$} & \multirow{2}{*}{ Additive/ Additive } \\
\hline & Ampicillin & $0.0625 / 0.125$ & $0.0313 / 0.0625$ & $0.5 / 0.5$ & & \\
\hline \multirow{2}{*}{$\begin{array}{l}\text { S. anginosus } \\
\text { ATCC } 31412\end{array}$} & CIE & $8 / 32$ & $2 / 8$ & $0.25 / 0.25$ & \multirow{2}{*}{$0.5 / 0.75$} & \multirow{2}{*}{ Synergistic/ Additive } \\
\hline & Ampicillin & $0.125 / 0.25$ & $0.0313 / 0.125$ & $0.25 / 0.5$ & & \\
\hline \multirow{2}{*}{$\begin{array}{c}\text { S. gordonii } \\
\text { ATCC } 10558\end{array}$} & CIE & $4 / 4$ & $1 / 2$ & $0.25 / 0.5$ & \multirow{2}{*}{$0.5 / 0.75$} & \multirow{2}{*}{ Synergistic/ Additive } \\
\hline & Ampicillin & $0.125 / 0.5$ & $0.0313 / 0.0625$ & $0.25 / 0.25$ & & \\
\hline \multirow{2}{*}{$\begin{array}{l}\text { A. actinomycetemcomitans } \\
\text { ATCC } 43717\end{array}$} & CIE & $32 / 64$ & $8 / 16$ & $0.25 / 0.25$ & \multirow{2}{*}{$0.5 / 0.375$} & \multirow{2}{*}{ Synergistic/ Synergistic } \\
\hline & Ampicillin & $8 / 32$ & $2 / 4$ & $0.25 / 0.125$ & & \\
\hline \multirow{2}{*}{$\begin{array}{l}\text { F. nucleatum } \\
\text { ATCC } 51190\end{array}$} & CIE & $16 / 32$ & $4 / 8$ & $0.25 / 0.25$ & \multirow{2}{*}{$0.5 / 0.75$} & \multirow{2}{*}{ Synergistic/ Additive } \\
\hline & Ampicillin & $16 / 32$ & $4 / 16$ & $0.25 / 0.5$ & & \\
\hline \multirow{2}{*}{$\begin{array}{l}\text { P. intermedia } \\
\text { ATCC } 49049\end{array}$} & CIE & $8 / 32$ & $2 / 8$ & $0.25 / 0.25$ & $0.5 / 0.75$ & Synergistic/Additive \\
\hline & Ampicillin & $2 / 4$ & $0.5 / 2$ & $0.25 / 0.5$ & & synergistic/ Auditve \\
\hline P. gingivalis & CIE & $2 / 8$ & $0.5 / 2$ & $0.25 / 0.25$ & $0.5 / 05$ & Sumpristic/Sungristic \\
\hline ATCC 33277 & Ampicillin & $0.25 / 0.5$ & $0.0625 / 0.125$ & $0.25 / 0.25$ & $0.5 / 0.5$ & synergistic/ synergistic \\
\hline
\end{tabular}

${ }^{1}$ The MIC and $\mathrm{MBC}$ of the CIE with ampicillin

${ }^{2}$ The fractional inhibitory concentration (FIC) index/fractional bactericical concentration (FBC) index

${ }^{3}$ American Type Culture Collection (ATCC)

${ }^{4}$ Korean collection for type cultures (KCTC) 
Table 3. Synergistic effects of CIE with gentamicin against oral bacteria

\begin{tabular}{|c|c|c|c|c|c|c|}
\hline \multirow{2}{*}{ Strains } & \multirow{2}{*}{ Agent } & \multicolumn{2}{|c|}{ MIC/MBC $(\mu \mathrm{g} / \mathrm{mL})$} & \multirow{2}{*}{ FIC } & \multirow{2}{*}{ FICI $^{2}$} & \multirow{2}{*}{ Outcome } \\
\hline & & Alone & Combination $^{1}$ & & & \\
\hline \multirow{2}{*}{$\begin{array}{c}\text { S. mutans } \\
\text { ATCC } 25175^{3}\end{array}$} & CIE & $16 / 32$ & $4 / 8$ & $0.25 / 0.25$ & \multirow{2}{*}{$0.5 / 0.75$} & \multirow{2}{*}{ Synergistic/ Additive } \\
\hline & Gentamicin & $16 / 16$ & $4 / 8$ & $0.25 / 0.5$ & & \\
\hline \multirow{2}{*}{$\begin{array}{l}\text { S. sanguinis } \\
\text { ATCC } 10556\end{array}$} & CIE & $8 / 32$ & $2 / 8$ & $0.25 / 0.25$ & \multirow{2}{*}{$0.5 / 0.75$} & \multirow{2}{*}{ Synergistic/ Additive } \\
\hline & Gentamicin & $16 / 32$ & $4 / 16$ & $0.25 / 0.5$ & & \\
\hline \multirow{2}{*}{$\begin{array}{l}\text { S. sobrinus } \\
\text { ATCC } 27607\end{array}$} & CIE & $32 / 32$ & $8 / 16$ & $0.25 / 0.5$ & \multirow{2}{*}{$0.5 / 0.75$} & \multirow{2}{*}{ Synergistic/ Additive } \\
\hline & Gentamicin & $16 / 32$ & $4 / 8$ & $0.25 / 0.25$ & & \\
\hline \multirow{2}{*}{$\begin{array}{c}\text { S. ratti } \\
\text { KCTC } 3294^{4}\end{array}$} & CIE & $16 / 32$ & $4 / 8$ & $0.25 / 0.25$ & \multirow{2}{*}{$0.5 / 0.75$} & \multirow{2}{*}{ Synergistic/ Additive } \\
\hline & Gentamicin & $16 / 32$ & $4 / 16$ & $0.25 / 0.5$ & & \\
\hline \multirow{2}{*}{$\begin{array}{c}\text { S. criceti } \\
\text { KCTC } 3292\end{array}$} & CIE & $32 / 64$ & $8 / 16$ & $0.25 / 0.25$ & \multirow{2}{*}{$0.5 / 0.75$} & \multirow{2}{*}{ Synergistic/ Additive } \\
\hline & Gentamicin & $8 / 16$ & $2 / 8$ & $0.25 / 0.5$ & & \\
\hline \multirow{2}{*}{$\begin{array}{l}\text { S. anginosus } \\
\text { ATCC } 31412\end{array}$} & CIE & $8 / 32$ & $2 / 4$ & $0.25 / 0.125$ & \multirow{2}{*}{$0.5 / 0.25$} & \multirow{2}{*}{ Synergistic/ Synergistic } \\
\hline & Gentamicin & $8 / 32$ & $2 / 4$ & $0.25 / 0.125$ & & \\
\hline \multirow{2}{*}{$\begin{array}{c}\text { S. gordonii } \\
\text { ATCC } 10558\end{array}$} & CIE & $4 / 4$ & $1 / 2$ & $0.25 / 0.5$ & \multirow{2}{*}{$0.5 / 0.75$} & \multirow{2}{*}{ Synergistic/ Additive } \\
\hline & Gentamicin & $16 / 32$ & $4 / 8$ & $0.25 / 0.25$ & & \\
\hline \multirow{2}{*}{$\begin{array}{c}A . \\
\text { actinomycetemcomitans } \\
\text { ATCC } 43717\end{array}$} & CIE & $32 / 64$ & $16 / 16$ & $0.5 / 0.25$ & \multirow{2}{*}{$1.0 / 0.75$} & \multirow{2}{*}{ Additive/ Additive } \\
\hline & Gentamicin & $16 / 32$ & $8 / 16$ & $0.5 / 0.5$ & & \\
\hline \multirow{2}{*}{$\begin{array}{l}\text { F. nucleatum } \\
\text { ATCC } 51190\end{array}$} & CIE & $16 / 32$ & $4 / 8$ & $0.25 / 0.25$ & \multirow{2}{*}{$0.75 / 0.5$} & \multirow{2}{*}{ Additive/ Synergistic } \\
\hline & Gentamicin & $2 / 8$ & $1 / 2$ & $0.5 / 0.25$ & & \\
\hline \multirow{2}{*}{$\begin{array}{l}\text { P. intermedia } \\
\text { ATCC } 25611\end{array}$} & CIE & $8 / 32$ & $2 / 4$ & $0.25 / 0.125$ & $0.5 / 0.25$ & Synergistic/ Synergistic \\
\hline & Gentamicin & $32 / 64$ & $8 / 8$ & $0.25 / 0.125$ & $0.5 / 0.25$ & synergistic synergistic \\
\hline P. gingivalis & CIE & $2 / 8$ & $0.5 / 2$ & $0.25 / 0.25$ & $0.5 / 0.375$ & Synergistic/ Synergistic \\
\hline ATCC 33277 & Gentamicin & $256 / 512$ & $64 / 64$ & $0.25 / 0.125$ & & syllergistic/ syllergistic \\
\hline
\end{tabular}

${ }^{1}$ The MIC and MBC of the CIE with gentamicin

${ }^{2}$ The fractional inhibitory concentration (FIC) index/fractional bactericical concentration (FBC) index

${ }^{3}$ American Type Culture Collection (ATCC)

${ }^{4}$ Korean collection for type cultures (KCTC)
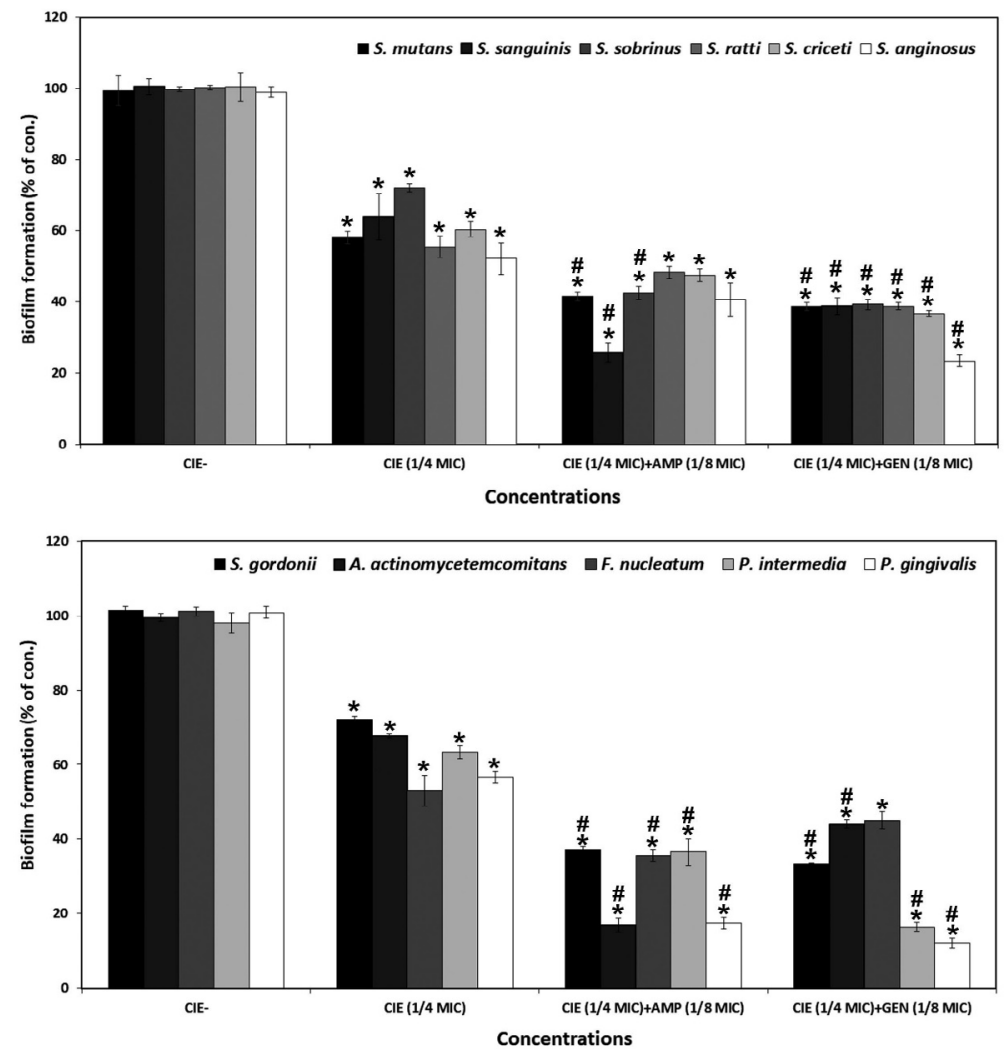

Figure 1. Anti-biofilm effect of different concentrations of CIE alone or/and antibiotics on biofilm formation of oral bacteria. Cells stained with $0.1 \%$ (wt/vol) crystal violet solution for $15 \mathrm{~min}$, washed with PBS, and de-stained with $96 \%$ ethanol $10 \mathrm{~min}$ in order to fix the cells. Thereafter, acetic acid was then added to each well and biofilm formation was quantified by measuring the absorbance of the solution at $540 \mathrm{~nm}$ using a microplate reader. Data points are the mean values $\pm \mathrm{SE}$ of six experiments. ${ }^{*} \mathrm{p}<0.05$ : significantly different from CIE- and $\# p<0.05$ : significantly different from CIE $(1 / 4 \mathrm{MIC})$ 


\section{Time kill of CIE with antibiotics}

Among several bioactive compounds isolated from C. indicum, acetylenic compounds and flavonoids potently inhibited NO production in macrophages [26]. Due to the potent antibacterial and anti-inflammatory activities, $C$. indicum extracts have been shown to effectively attenuate the development of skin diseases, such as atopic dermatitis and ear edema, in animal models [23]. The bacterial effect of CIE with antibiotics, ampicillin and gentamicin against oral bacteria was confirmed by time-kill curve experiments. The CIE (MIC or $\mathrm{MIC}_{50}$ ) alone resulted rate of killing increasing or not changing in CFU/ $\mathrm{ml}$ at time dependent manner, with a more rapid rate of killing by CIE $\left(\mathrm{MIC}_{50}\right)$ with ampicillin and gentamicin $\left(\mathrm{MIC}_{50}\right)$ (Figures 2 and 3). A strong bactericidal effect was exerted in drug combinations.
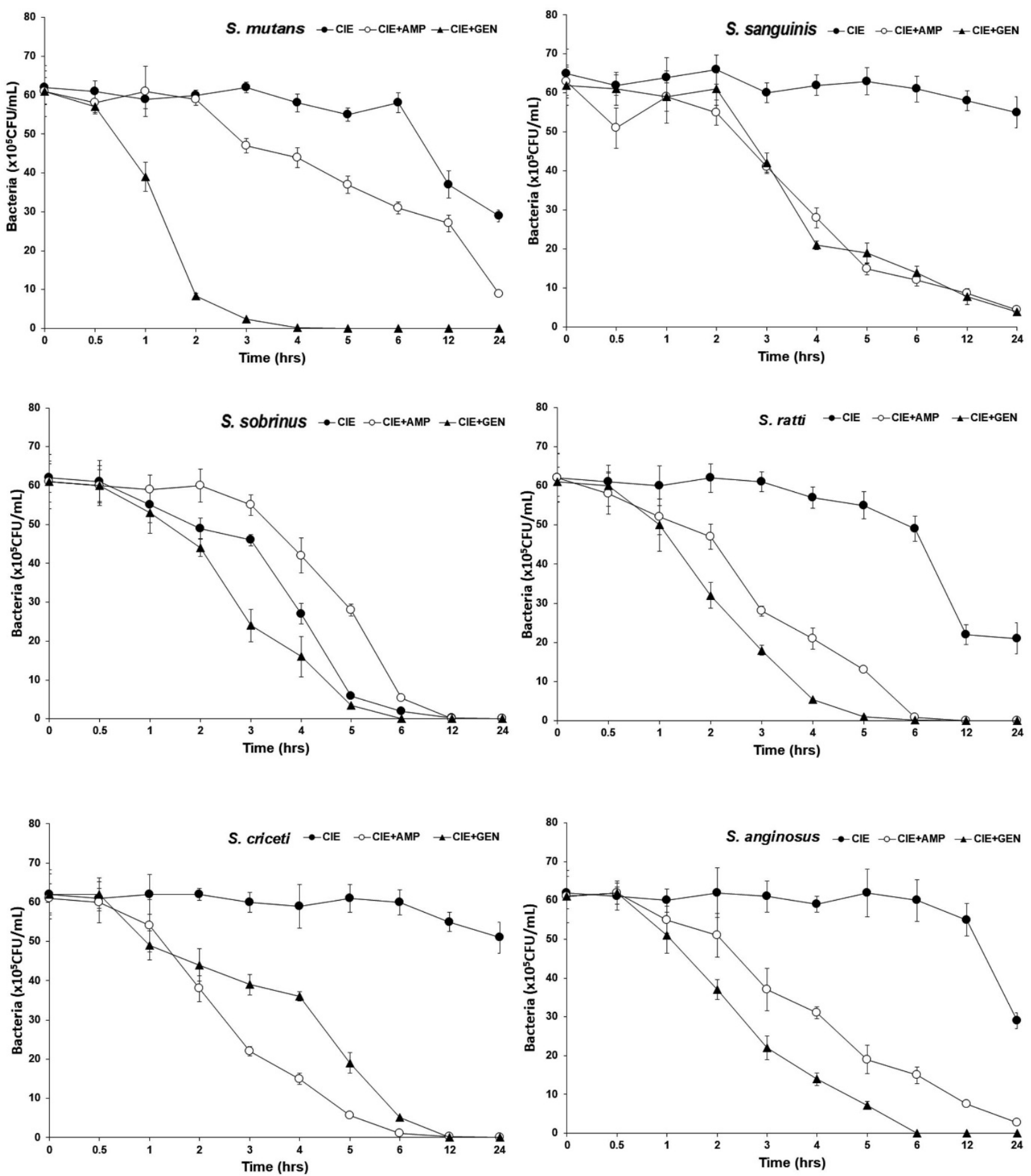

Figure 2. Time-kill curves of MIC of CIE alone and its combination with $\mathrm{MIC}_{50}$ of AMP or/and GEN against S. mutans, S. sanguinis, S. sobrinus, S. anginosus, S. criceti, and S. ratti. Bacteria were incubated with $\mathrm{CIE}(\bullet), \mathrm{CIE}+\mathrm{AMP}(\circ)$, and CIE + GEN $(\boldsymbol{\Delta})$ over time. Data points are the mean values \pm SE of six experiments. CFU, colony-forming units 

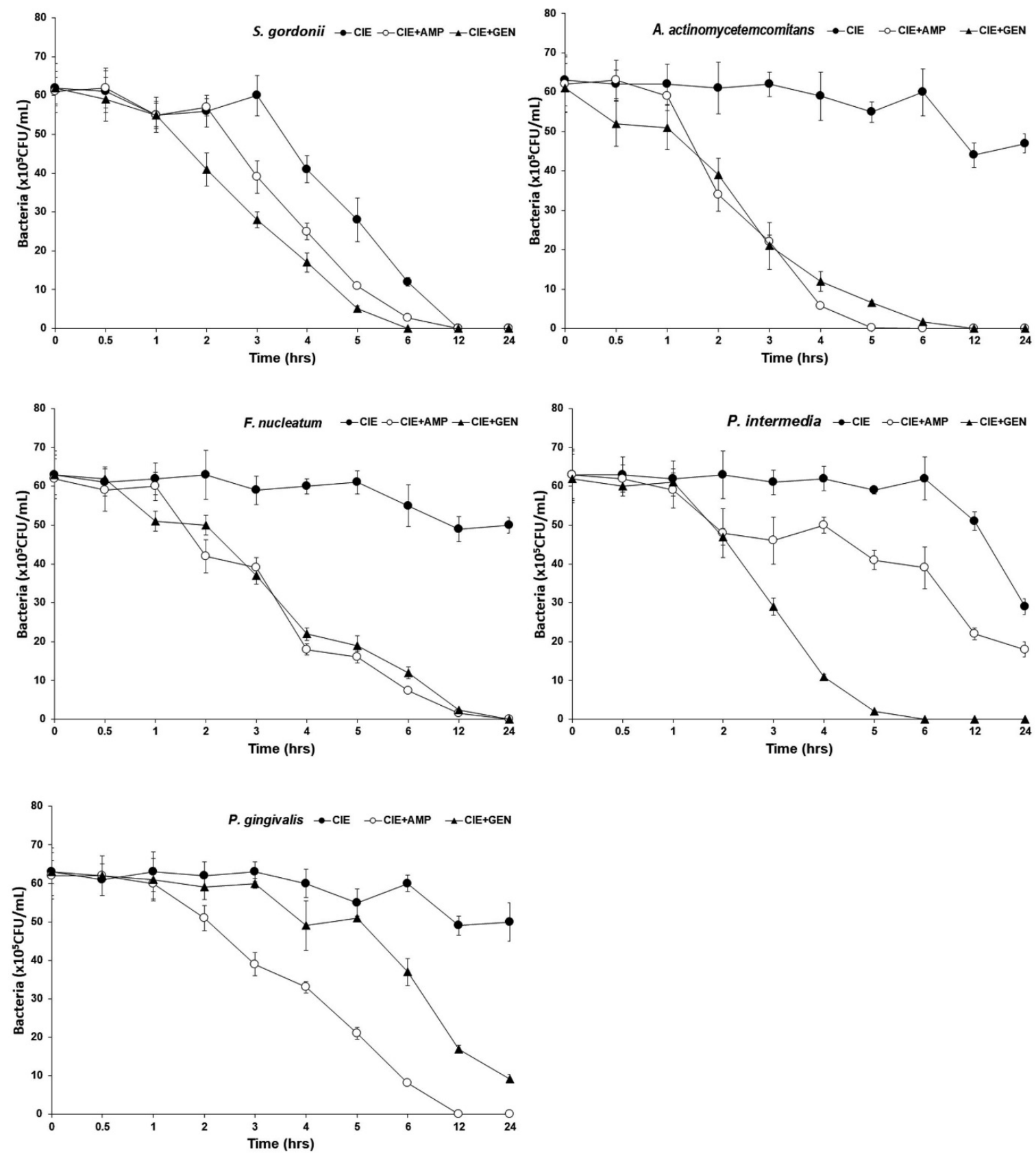

Figure 3. Time-kill curves of MIC of CIE alone and its combination with $\mathrm{MIC}_{50}$ of AMP or/and GEN against $S$. gordonii, A. actinomycetemcomitans, F. nucleatum, P. intermedia, and $P$. gingivalis. Bacteria were incubated with CIE $(\bullet), \mathrm{CIE}+\mathrm{AMP}(\circ)$, and CIE + GEN ( $\boldsymbol{\Delta})$ over time. Data points are the mean values \pm SE of six experiments. CFU, colony-forming units

In conclusion, these findings suggest that CIE fulfills the conditions required of a novel cariogenic bacteria and periodontal pathogens, particularly bacteroides species drug and may be useful in the future in the treatment of oral bacteria.

\section{Declaration of interest}

The authors declare no conflicts of interest.

\section{Sources of funding}

This study was not funded by any organization.

\section{Ethical approval}

This study has no need for prior approval by an ethics committee.

\section{References}

1. Colombo APV, Tanner ACR (2019) The Role of Bacterial Biofilms in Dental Caries and Periodontal and Peri-implant Diseases: A Historical Perspective. J Dent Res 98: 373-385. [Crossref]

2. Scannapieco FA, Cantos A (2016) Oral inflammation and infection, and chronic medical diseases: implications for the elderly. Periodontol 2000 72: 153-175.

3. Hodgdon A (2013) Dental and related infections. Emerg Med Clin North Am 31: 465480. [Crossref] 
4. Larsen T, Fiehn NE (2017) Dental biofilm infections - an update. APMIS 125: 376-384. [Crossref]

5. Legéñová K, Bujdáková $\mathrm{H}$ (2015) The role of Streptococcus mutans in the oral biofilm. Epidemiol Mikrobiol Imunol 64: 179-187. [Crossref]

6. Marsh PD, Zaura E (2017) Dental biofilm: ecological interactions in health and disease. J Clin Periodontol 44: S12-S22.

7. Seneviratne CJ, Zhang CF, Samaranayake LP (2011) Dental plaque biofilm in oral health and disease. Chin J Dent Res 14: 87-94. [Crossref]

8. Pasich E, Walczewska M, Pasich A, Marcinkiewicz J (2013) [Mechanism and risk factors of oral biofilm formation]. Postepy Hig Med Dosw (Online) 67: 736-741. [Crossref]

9. Borgnakke WS (2015) Does Treatment of Periodontal Disease Influence Systemic Disease? Den Clin North Am 59: 885-917.

10. Han YW, Houcken W, Loos BG, Schenkein HA, Tezal M (2014) Periodontal disease, atherosclerosis, adverse pregnancy outcomes, and head-and-neck cancer. $A d v$ Dent Res 26: 47-55. [Crossref]

11. Levine RS (2013) Obesity, diabetes and periodontitis--a triangular relationship? $\mathrm{Br}$ Dent J 215: 35-39. [Crossref]

12. Mira A, Simon-Soro A, Curtis MA (2017) Role of microbial communities in the pathogenesis of periodontal diseases and caries. J Clin Periodontol 44 Suppl 18: S2323S38. [Crossref]

13. Willems HM, Xu Z, Peters BM (2016) Polymicrobial biofilm studies: from basic science to biofilm control. Curr Oral Health Rep 3: 36-44. [Crossref]

14. O'Toole GA (2011) Microtiter dish biofilm formation assay. J Vis Exp. [Crossref]

15. Chinsembu KC (2016) Plants and other natural products used in the management of oral infections and improvement of oral health. Acta Trop 154: 6-18. [Crossref]

16. Mishra BB, Tiwari VK (2011) Natural products: an evolving role in future drug discovery. Eur J Med Chem 46: 4769-4807. [Crossref]

17. Ren AN, Wang ZG, Lu ZC, et al. (1999) Study on bacteriostasis and antivirotic of i $\neg$,owers Chrysanthemum indicum. Pharm Biotechnol 6: 241-244.

18. Arokiyaraj S, Arasu MV, Vincent S, et al. (2014) Rapid green synthesis of silver nanoparticles from Chrysanthemum indicum $\mathrm{L}$ and its antibacterial and cytotoxic effects: an in vitro study. Int J Nanomedicine 9: 379-388.

19. Jeong SC, Kim SM, Jeong YT, et al. (2013) Hepatoprotective effect of water extract from Chrysanthemum indicum Linn. Chin Med 8: 7.

20. Baek JM, Kim JY, Cheon YH, Park SH, Ahn SJ, et al. (2014) Dual Effect of Chrysanthemum indicum Extract to Stimulate Osteoblast Differentiation and Inhibit Osteoclast Formation and Resorption In Vitro. Evid Based Complement Alternat Med 2014: 176049. [Crossref]

21. Cheon MS, Yoon T, Lee do Y, et al. (2009) Chrysanthemum indicum Linne extract inhibits the inï $\neg$,ammatory response by suppressing NF-kappaB and MAPKs activation in lipopolysaccharide-induced RAW 264.7 macrophages. J Ethnopharmacol 122: 473477.

22. Lee do Y, Choi G, Yoon T, et al. (2009) Anti-inflammatory activity of Chrysanthemum indicum extract in acute and chronic cutaneous inflammation. J Ethnopharmacol 123: 149-154.

23. Matsuda H, Morikawa T, Toguchida I, Harima S, Yoshikawa M (2002) Medicinal flowers. VI. Absolute stereostructures of two new flavanone glycosides and a phenylbutanoid glycoside from the flowers of Chrysanthemum indicum L.: their inhibitory activities for rat lens aldose reductase. Chem Pharm Bull (Tokyo) 50(7): $972-$ 975 .

24. Xue GM, Li XQ, Chen C, Chen K, Wang XB, et al. (2018) Highly oxidized guaianolide sesquiterpenoids with potential anti-inflammatory activity from Chrysanthemum indicum. J Nat Prod 81: 378-386. [Crossref]

25. Yang WS, Kim D, Yi YS, Kim JH, Jeong HY, et al. (2017) AKT-targeted antiinflammatory activity of the methanol extract of Chrysanthemum indicum var. albescens. J Ethnopharmacol 201: 82-90. [Crossref]

26. Luyen BT, Tai BH, Thao NP, Cha JY, Lee HY, et al. (2015) Anti-inflammatory components of Chrysanthemum indicum flowers. Bioorg Med Chem Lett. 25: 266-269.

27. Shunying Z, Yang Y, Huaidong Y, Yue Y, Guolin Z (2005) Chemical composition and antimicrobial activity of the essential oils of Chrysanthemum indicum. $J$ Ethnopharmacol 96: 151-158.
28. AridoÄŸan BC1, Baydar H, Kaya S, Demirci M, OzbaÅŸar D, et al. (2002) Antimicrobial activity and chemical composition of some essential oils. Arch Pharm Res 25: 860-864. [Crossref]

29. Hemaiswarya S, Kruthiventi AK, Doble M (2008) Synergism between natural products and antibiotics against infectious diseases. Phytomedicine 15: 639-652.

30. Climo MW, Patron RL, Archer GL (1999) Combinations of vancomycin and betalactams are synergistic against staphylococci with reduced susceptibilities to vancomycin. Antimicrob Agents Chemother 43: 1747-1753.

31. Jeong SI, Kim BS, Keum KS, Lee KH, Kang SY, et al. (2013) Kaurenoic acid from Aralia continentalis inhibits biofilm formation of Streptococcus mutans. Evid Based Complement Alt Med 2013: 160592.

32. Arweiler NB, Netuschil L (2016) The Oral Microbiota. Adv Exp Med Biol 902: 45-60. [Crossref]

33. López R, Smith PC, Göstemeyer G, Schwendicke F (2017) Ageing, dental caries and periodontal diseases. J Clin Periodontol 44 Suppl 18: S145-145S152. [Crossref]

34. Abdulbaqi HR, Himratul-Aznita WH, Baharuddin NA (2016) Anti-plaque effect of a synergistic combination of green tea and Salvadora persica L. against primary colonizers of dental plaque. Arch Oral Biol 70: 117-124. [Crossref]

35. Bonifait L, Grenier D (2010) Cranberry polyphenols: potential benefits for dental caries and periodontal disease. $J$ Can Dent Assoc 76: a130. [Crossref]

36. Pitinidhipat N, Yasurin P (2012) Antibacterial Activity of Chrysanthemum indicum, Centella asiatica and Andrographis paniculata against Bacillus cereus and Listeria monocytogenes under Osmotic Stress. AU J T 15: 239-245.

37. Seukep JA, Fankam AG, Djeussi DE, Voukeng IK, Tankeo SB, et al. (2013) Antibacterial activities of the methanol extracts of seven Cameroonian dietary plants against bacteria expressing MDR phenotypes. Springerplus 2: 363. [Crossref]

38. Van Strydonck DA, Slot DE, Van der Velden U, Van der Weijden F (2012) Effect of a chlorhexidine mouthrinse on plaque, gingival inflammation and staining in gingivitis patients: a systematic review. J Clin Periodontol 39: 1042-1055.

39. Boyle P, Koechlin A, Autier P (2014) Mouthwash use and the prevention of plaque, gingivitis and caries. Oral Dis 20 Suppl 1: 1-68. [Crossref]

40. Gupta S, Laskar N, Kadouri DE (2016) Evaluating the Effect of Oxygen Concentrations on Antibiotic Sensitivity, Growth, and Biofilm Formation of Human Pathogens. Microbiol Insights 9: 37-46. [Crossref]

41. Pandit S, Kim H J, Park SH, Jeon JG (2012) Enhancement of fluoride activity agains Streptococcus mutans biofilms by a substance separated from Polygonum cuspidatum. Biofouling 28: 279-287.

42. Baehni PC, Takeuchi Y (2003) Anti-plaque agents in the prevention of biofilmassociated oral diseases. Oral Dis 9 Suppl 1: 23-29. [Crossref]

43. Bhardwaj P, Krishnappa S (2014) Various approaches for prevention of Dental caries with emphasis on Probiotics: A review. J Dent Med Sci 1: 62-67.

44. Wang HY, Cheng JW, Yu HY, Lin L, Chih YH, et al. (2015) Efficacy of a novel antimicrobial peptide against periodontal pathogens in both planktonic and polymicrobial biofilm states. Acta Biomaterialia 25: 150-161.

45. Jang EJ, Cha SM, Choi SM, Cha JD (2014) Combination effects of baicalein with antibiotics against oral pathogens. Arch Oral Biol 59: 1233-1241. [Crossref]

46. Gürsoy UK, Gürsoy M, Könönen E, Sintim HO (2017) Cyclic dinucleotides in ora bacteria and in oral biofilms. Front Cell Infect Microbiol 7: 273. [Crossref]

47. Feldman M, Grenier D (2012) Cranberry proanthocyanidins act in synergy with licochalcone A to reduce Porphyromonas gingivalis growth and virulence properties, and to suppress cytokine secretion by macrophages. J Appl Microbiol 113: 438-447.

48. Yamanaka A, Kimizuka R, Kato T, Okuda K (2004) Inhibitory effects of cranberry juice on attachment of oral streptococci and biofilm formation. Oral Microbiol Immunol 19: 150-154.

Copyright: (C2019 Lee K. This is an open-access article distributed under the terms of the Creative Commons Attribution License, which permits unrestricted use, distribution, and reproduction in any medium, provided the original author and source are credited. 